\title{
下咽頭頸部食道癌の遠隔成績一1979年〜1982年一
}

\author{
北里大学医学部耳鼻咽喉科学教室（主任：設楽哲也教授） \\ 岡·本 牧人, 高橋 廣臣, 八尾和雄, 古川浩三
}

\section{LONG TERM RESULTS OF TREATMENT FOR CARCINOMA OF THE HYPOPHARYNX AND CERVICAL ESOPHAGUS}

\author{
MAKITO OKAMOTO, M.D., HIROOMI TAKAHASHI, M.D., KAZUO YAO, M.D. \\ and KOZO FURUKAWA, M.D.
}

Department of Otorhinolaryngology, School of Medicine, Kitasato University, Sagamihara

Seventeen cases of carcinoma of the hypopharynx and the cervical esophagus who had been treated from 1979 to 1982 at Kitasato University Hospital were investigated retrospectively. Fourteen of them were advanced cases.

Nine patients were alive for more than five years. Seven were alive with no evidence of the disease, one was alive with reccurrent disease in the cervical lymph nodes and could not be followed up after five years.

Six patients died of original disease, in addition to them, one died suddenly of unknown cause after eleven months and one died of gastric cancer after 39 months. No evidence or original disease was seen in the latter two.

Five-year survival rate was $53 \%(9 / 17)$ in total cases and $69 \%(9 / 13)$ excluding two cases died of other causes and two who refused the surgical therapy.

Key words : 下咽頭癌, 頸部食道癌, 治療法, 5 年生存率

A $91-1375-53389$

1.はじめに

下咽頭頸部食道癌は頭頸部腫偒の中でも予後不良の 疾患の一つである11.我々は, 1979年 1 月より1982年12 月までに北里大学病院耳鼻咽喉科腫瘍外来にて治療を 開始した下咽頭頸部食道癌患者17例について検討した 結果，比較的良好な成績を収めることができたので報 告する。

\section{2. 症 例 構成}

症例の内訳は, 男性 11 例, 女性 6 例, 年齢は 40 歳か ら78歳, 平均60歳であった。70歳以上の高齢者は 4 名 であった。

TNM 分類は表 1 に示すが, 病期別分類 (UICC1978)
は I 期 1 例，II期 2 例，III期 7 例，IV期 7 例であった。 部位別分類は, 梨状楩凹 9 例, 輪状後部 6 例, 後壁 2 例であった。

病理学的分類は, 高分化型扁平上皮癌 8 例, 中等度 分化型扁平上皮癌 5 例, 低分化型扁平上皮癌 3 例, 末 分化癌 1 例であった。

\section{3. 結 果}

初回治療を放射線治療, 手術療法, 化学療法に分け, 各治療法毎の症例数と成績を示す。

1）放射線治療

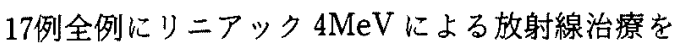
施行した。 1 回線量は $2 \mathrm{~Gy}$, 総線量は $20 \mathrm{~Gy}$ から $70 \mathrm{~Gy}$ 
表 1 症例の TN 分類

\begin{tabular}{rrrrrr}
\hline & N 0 & N 1 & N 2 & N 3 & 計 \\
\hline T 1 & $0 / 1$ & $3 / 3$ & 0 & $0 / 2$ & $3 / 6$ \\
$\mathrm{~T} 2$ & $2 / 2$ & $1 / 1$ & 0 & $1 / 3$ & $4 / 6$ \\
$\mathrm{~T} 3$ & $1 / 2$ & $1 / 1$ & 0 & $0 / 2$ & $2 / 5$ \\
$\mathrm{~T} 4$ & 0 & 0 & 0 & 0 & 0 \\
\hline 計 & $3 / 5$ & $5 / 5$ & 0 & $1 / 7$ & $9 / 17$ \\
\hline & & & (5 年生存例 / 症例数)
\end{tabular}

て，42Gy 以下の術前照射群 ( 8 例) と 60Gy 以上の根 治照射群（9例）に分けられた。照射野は表 2,3 に 示す。

根治照射群は，(1)根治照射で根治治療の期待できる もの，すなわち，N2 まででかつ T1（梨状窝原発では T2)までのもの, 逆に, (2)椎前筋膜, 深頸筋膜をこえ て根治手術の困難なもの,抢よび(3)手術拒否例である. 術前照射群は, 輪状後部では T1 から, その他の部位で
は T2 以上の症例に，また，N3 でも手術可能と思われ る例はこれに含めた。

術前照射群の照射量は $20 \mathrm{~Gy}, 26 \mathrm{~Gy}, 30 \mathrm{~Gy}$ が各 2 例, $32 \mathrm{~Gy} ， 42 \mathrm{~Gy}$ 各 1 例であった (表 2 ). 照射量は上頑癌 治療の経験2) と放射線治療によるリンパ球動態の検 討 ${ }^{3)}$ から 20-30Gy を目標とした。まず手術日を決定 し，照射開始日まで逆算して照射量を決定した。 $42 \mathrm{~Gy}$ 照射例は，外科との手術日の調整がうまくいかず，や むをえず照射量を増やした症例である。 5 例 $63 \%$ 5 年生存が得られた，N3の 2 例はいずれも死亡時Nの 再発はなかった。

根治照射群では $60 \mathrm{~Gy}$ が 5 例でもっとも多く, 70Gy が 3 例，68Gy が 1 例であった（表 3 ）。T1-2N0-1の 4 例中 3 例は手術なしに 5 年生存している. 死亡した 1 例は $20 \mathrm{~Gy}$ で手術を計画したものの患者の拒否に会 い，4.5力月かかって 70Gy まで照射した輪状後部癌 (T1N0)であった. 一方, N3の 5 例中 5 年生存してい るのは67歳男性の梨状陌山癌(T2N3)で FT207, SPG

表 2 術前照射例

\begin{tabular}{rccccccrrrr}
\hline NO. & 年齢 & 性 & 部位 & $\mathrm{T}$ & $\mathrm{N}$ & $\begin{array}{c}\text { 線量 } \\
\mathrm{Gy}\end{array}$ & $\begin{array}{c}\text { 照射野 } \\
\mathrm{cm}^{2}\end{array}$ & $\begin{array}{r}\text { 初診から } \\
\text { 放治開始 }\end{array}$ & $\begin{array}{c}\text { 放 治 後 } \\
\text { 手術まで }\end{array}$ & 5 年生存 \\
\hline 1 & 49 & 女 & P C & 2 & 0 & 20 & 69.5 & 9 日 & 11 日 & + \\
2 & 58 & 女 & P S & 2 & 3 & 20 & 179.4 & 10 日 & 14 日 & - \\
3 & 63 & 女 & P S & 2 & 0 & 26 & 51.9 & 4 日 & 18 日 & + \\
4 & 63 & 女 & P C & 1 & 1 & 26 & 85.8 & 24 日 & 20 日 & + \\
5 & 46 & 男 & P W & 3 & 0 & 30 & 34.0 & 9 日 & 9 日 & + \\
6 & 65 & 男 & P C & 1 & 3 & 30 & 165.4 & 14 日 & 29 日 & - \\
7 & 47 & 男 & P C & 3 & 1 & 32 & 70.3 & 9 日 & 13 日 & + \\
8 & 53 & 男 & P S & 3 & 0 & 42 & 100.3 & 6 日 & 104 日 & - \\
\hline
\end{tabular}

表 3 根治照射例

\begin{tabular}{ccccccccccc}
\hline NO. & 年齢 & 性 & 部位 & $\mathrm{T}$ & $\mathrm{N}$ & $\begin{array}{c}\text { 線量 } \\
\mathrm{Gy}\end{array}$ & $\begin{array}{c}\text { 照射野 } \\
\mathrm{cm}^{2}\end{array}$ & $\begin{array}{c}\text { 初診から } \\
\text { 放治開始 }\end{array}$ & $\begin{array}{c}\text { 放 治 後 } \\
\text { 手術まて }\end{array}$ & 5 年生存 \\
\hline 9 & 66 & 男 & P W & 1 & 1 & 60 & 67.2 & 7 日 & なし & + \\
10 & 40 & 男 & P S & 1 & 1 & 60 & 85.6 & 37 日 & 術後照射 & + \\
11 & 78 & 男 & P S & 2 & 1 & 60 & 92.4 & 7 日 & なし & + \\
12 & 62 & 女 & P S & 2 & 3 & 60 & 41.8 & 5 日 & 66 口 & - \\
13 & 70 & 男 & P C & 3 & 3 & 60 & 105.6 & 6 日 & なし & - \\
14 & 51 & 男 & P S & 1 & 3 & 68 & 112.0 & 49 日 & 56 日 & - \\
15 & 75 & 男 & P C & 1 & 0 & 70 & 119.2 & 39 日 & 拒否 & - \\
16 & 67 & 男 & P S & 2 & 3 & 70 & 109.7 & 11 日 & 96 日 & + \\
17 & 73 & 男 & P S & 3 & 3 & 70 & 105.6 & 6 日 & 拒否 & -(不明) \\
\hline
\end{tabular}


併用の 1 例のみであった。 3 例は明らかにNのコント ロールができなかった。

\section{2) 手術療法}

一次治療として原発巣, 転移巣の少なくとも一つに 対して手術を施行したのは12例であった。手術しなか った 5 例は拒否 2 例, 手術以外で一次治瘾 3 例（ただ し, 1 例は 5 年を過ぎて再発し咽頭喉頭頸部食道摘出 施行, 1 例は 3 年 3 力月で他癌死）であった。

手術した12例のうち手術を先行したのは 1 例であっ た。この症例は40歳男性 (T1N1) て $6 \times 8 \mathrm{~cm}$ の可動性 のある左頸部腫瘤を主訴として来院し, 腫場の転移, 炎症性疾患等を考えて精查したが診断がつかず，頸部 生㾇摘出術にて扁平上皮癌と診断された。そこで, 食 道透視, ガリウムスキャン, 胸部 CT, 上咽頭生検, 気 管支鏡検査, 食道鏡検查を施行したが原発巣を特定で きなかった，摘出術 2 週後に全身麻酔下に再度食道鏡 検査を施行し, ランダムバイオプシーの結果, 梨状窝 原発が明らかとなった．初診から原発巣確定まで33日 を要した。

残り11例の手術はすべて放射線治嘡後である.

原発巣に対する手術はすべて咽頭喉頭頸部食道摘出 術で10例に施行した，N3の1例で患側のみ頸部郭清 術を併用した以外, 両側頸部郭清術を併用した。食道 再建には DP 皮弁 6 例, 大胸筋筋皮弁 3 例, 有茎結腸 1 例で，DP 皮弁の 3 例と大胸筋筋皮弁の 2 例の計 5 例 $50 \%$ が 5 年生存している.

残りの 1例 (T2N3) は70Gy 照射後も頸部腫瘤は残 存し経過観察をつづけていたが, 増大傾向があり照射 終了より96日後に患側頸部郭清術を施行した。しかし， 病理検索の結果腫湯の残存は認められなかった。 5 年 生存が得られている。

3) 化学療法

化学療法についてはこの期間系統的には施行されな 加た。一次治療に化学療法を併用したのは 8 例であ つた.

FT207を使用した 3 例はいずれも放射線治療と同

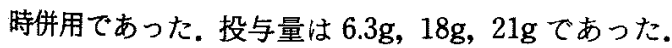
BLM は 2 例で 1 例はテストドース $(5 \mathrm{mg})$ で薬疹がで て中止した. 1 例は $60 \mathrm{mg}$ を放射線と併用した.ペプレ オマイシンは 2 例で 1 例は $55 \mathrm{mg}$ 放射線と併用した。 1例は $95 \mathrm{mg}$ でシスプラチンと併用した。シスプラチ ンは 2 例でペプレオマイシンと併用の 1 例と単独で induction chemotherapyとして用いた 1 例であった。

FT207の 3 例は 5 年生存しているが, その他の 5 例
は全例 5 年以内に死亡した。

非特異的免疫療法は 7 例に施行した. Polysaccaride -Kreha (PSK) を，投与したのは 2 例で，1例は治療 開始と同時に，1例は手術後よりで，2例とも5 年生 存している現在も投与をつづけている゙. Schizophyllan (SPG) を投与したのは 5 例で主に放射線治療に併 用した. 総投与量は $120 \mathrm{mg}$ から $360 \mathrm{mg}$ であった のうち 3 例が 5 年生存している.

4）全体の予後

17 例中 5 年以上生存が 9 例, 死亡例 7 例, 追跡不能 例 1 例であった。

生存例のうち 7 例は現在も癌なく経過観察中, 1 例 は担癌（頸部転移あるが手術拒否）生存，1例はその 後追跡不能であった。

死亡例（7 例）の内訳は，原病死 5 例, 他癌死 1 例, 原因不明の突然死 1 例であった。原病死 5 例は, 局所 および頸部がコントロールできなかったもの 2 例, 胸 腔内敷石状転移がコントロールできなかったもの 1 例, 遠隔転移 (肺, 乳房) 1 例, 手術拒否による局所 死 1 例であった。

他癌死例は 3 年 3 力月生存した。死因は胃癌で病理 解剖でも扁平上皮癌はなかった。

原因不明の突然死 1 例は11力月生存で，一過性脳虚 血発作様の症状を来し数日入院したが，退院した翌日 に死亡した。臨床的に癌はなかったが病理解剖はでき なかった。

追跡不能の 1 例は放射線治療後手術拒否し近医に転 院したもので，予後不明であるが転院時担癌であり， 死亡例に含めた（表 3).

5 年生存率は全例で $53 \%(9 / 17)$, 不明例, 拒否例を 除くと $60 \%(9 / 15)$ ，他癌死，原因不明死を除くと.69\% (9/13)であった. 死亡例の平均生存期間は19力月であ った.

角化型扁平上皮癌では 8 例中 6 例が，非角化型扁平 上皮癌では 5 例中 4 例が 5 年生存しているが，低分化 型扁平上皮癌および未分化癌では 5 年生存は得られな かった。

\section{4. 考 察}

下咽頭癌の予後不飠因子として次の上うなものが挙 げられる．成績の向上のためにはこれらを解決してい く必要があるが現実には必ずしも容易ではない。

1) 進行例が多い.

予後不良の原因の大部分がこれによるとする報告も 
ある ${ }^{6)}$.我々の症例でも病期分類でIII 期IV期は $82 \%$

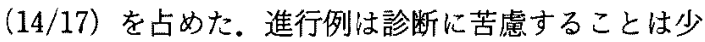
ないが，頸部腫瘤のみの症例の場合原発巣の特定まで に時間がかかる例があった．治癒率の向上には早期発 見が望まれるがいまだ十分とはいえない。

初診時から治療開始までの期間は平均13日で 1 週間 以内が 7 例 $41 \%$ であった. 生存例は平均 10 日, 死亡例 は平均16日であり，扁平上皮癌に扔ける数日の差は大 きいと考えており，診断後直ちに治療するという意味 での早期治療を心がけた。

2）高齢者が多い.

今回の症例で70歳以上は 4 例 $24 \%$ と多くなかったこ とは幸いであった，高齢者の問題点は二つあって，第 一は肉体的ハンデキャップである。合併症を有するこ とが多く，全身的要因により手術不可となったり，た とえ手術はできてもその後の回復が悪く，結果的に手 術侵襲に耐えられなかったと考えられる症例があっ た。これに対しては麻醉技術の進歩, 術前, 術後の全 身管理, 手術時間の短縮等の対処が必要である. 第二 は老いて，病んで声が出ず，なお生きていくという意 欲の問題である，特に核家族化と経済的負担が加わっ て問題を更に複雑にしている。この問題の解決は容易 ではない．ただ，平均寿命の延びに伴い元気な高齢者 も增えてきているので，年跉だけで治療適応を画一的 に決めることはできない.

3) 手術拒否

上の問題とも関連するが, 声が出なくなること, 鼻 から管を入れること, 首に孔が開くことは, 少なくと も今まで自分は正常と思ってきた人にとってはにわか に受け入れがたい状態である. 中でも問題はコミュニ ケーションの手段を失う恐怖と自覚症状のない部分を 奪われる気持から, 手術拒否の最大の理由である。し かし, 今後術前照射, 手術というプロトコールを進め る場合，患者自身の納得の期間は非常に短いものとな る.これに対して, 声を保存する努力は喉頭癌の T3, T4でも下咽頭癌でも試みてきたが7，特に後者ではそ の成績は十分とはいえず，誤䁩の問題も年をとるにつ れて多くなる。これらのことから，喉頭摘出を納得し てもらった上で，術後の音声機能の獲得を当院の音声 言語外来でフォローアップするよう努力している ${ }^{8)}$.

しかし, 治療拒否は, 人生観, 哲学, 宗教の分野と からみ, 医学, 医療だけでは解決できないこともしば しばでややむをえず姑息的治療を選択せざるを得ない こともある゙

\section{4）食事摄取不可}

経口摄取ができないことは肉体的にはもちろんであ るが，精神的消耗も無視できない.

治療前は嶼下障害による肉体的消耗が大きく，これ に対しては経口, 経管栄養剂の普及, 高カロリー翰液, 胃瘦の造設等を行ってきた ${ }^{10)}$. 胃㿉の造設は,外から管 がみえず，治療野を管が通らないので，うっとうしさ からも美観からもすぐれており，患者にも概ね好評で ある、術後経口摂取ができるまで時間のかかった DP 皮弁時代には特に有用であった．欠点としては，手術 侵襲を伴うこと，外科に依頼するので時間がかかり， 原疾患治療との調整に困難が生じることがある点であ る.

しかし，この問題は主として DP 皮弁時代のものて あり，一期的再建の進歩によりほほ解決された。食道 の一期的再建は DP 皮弁でも試みられてきたが，一般 に普及したのは筋皮弁の導入によってである゙”，その 手技に関しては村上 ${ }^{12)}$ をはじめ多くの報告があるの でここではのべないが，筋皮弁は食事摄取の問題ばか りでなく，次に述べる摘出範囲の拡大にも大いに貢献 した.

\section{5）断端再発}

咽頭，食道断端再発に対してはなるべく上下方向に 大きくとるように心がけている，すなわち，筋皮弁の 採用により，咽頭側は口蓋扁桃の高さまで取っても余 裕をもって一次再建が可能であり, 治瘾率の向上に奇 与していると思われた。後壁の筋層は粘膜断端よりさ らに上まで切除するよう心がけている．肛側端は比較 的 surgical margin をとりやすいが，第 1 胸椎をこえ る症例は食道全抜去し胃管挙上による再建に移行して いる.

頸部郭清に関しては，他の頭頸部領域では予防的郭 清は行わない方針であるが13)，下咽頭では患側のみな らず健側にも潜在転移する頻度が高いといわれてわ $り^{14315)}$ 両側頸部郭清を原則とした．また，気管傍リン パ節を十分郭清しているが，胸骨柄部は開胸によって も郭清できない部分であり, 今後の再発傾向をみて対 忘を考える必要があると思われた ${ }^{16)}$.

6) 敷石状転移

食道の敷石状転移は $14.3 \%$ にみられるという報告も ある ${ }^{17)}$.今回みられた 1 例では, 開胸により合併切除を 試みたが結局胸腔内の制御ができなかった，本症例は 42Gy 照射後, 手術までの期間が104日と長く, 他科と の連携の難しさを感じた。 


\section{7) 遠隔転移}

放射線，手術療法とも主として局所に対する治療で あり，遠隔転移に対処するのは化学療法がもつとも有 利と思われる. 今回の症例は系統的化学療法は行わな かったが，遠隔転移死は幸いにも1例であった，しか し, 化学療法を系統的に組み入れた岡田ら ${ }^{18)}$ の報告に よれば，局所，頸部転移死は減るが遠隔転移死が増え るという。この点については生存期間を含めた検討が 今後の課題であるが，化学療法，放射線療法とも両刃 の剣といわれ過量になると個体のもつ免疫力を弱める こともあるだろう. 症例数も少なく，対照もないが， 非特異的兔疫療法併用例の予後がよかったことは遠隔 転移の少なかったことと合わせ考えると興味深い。こ れも今後のコントロールスタディの検討が待たれる点 である。

以上，下咽頭頸部食道癌の予後不良因子とその対処 法について考察した. 対象症例は, 歴史的には, DP 再 建の完成期および一期的再建の導入期, 扁平上皮癌に 有効で副作用の少ない化学療法剤の開発と非特異的免 疫療法の概念が登場した時期であった。これら 3 者を 画一的にではなく，予後不良因子を考慮しつつ集学的 に組み合わせて行ったことが予後向上に寄与した最大 の理由であると考えている。

\section{5.おわりに}

1979年から1982年までの下咽頭頸部食道癌の治療成 績について検討した。

1. 17 例中 9 例が 5 年以上生存した。 うち， 7 例は 癌なし，1例は担癌生存，1例はその後追跡不能であ つた.

2. 死亡例の内訳は, 原病死 6 例, 他癌死 1 例, 原 因不明の突然死 1 例であった。

3，5年生存率は全例で53\%（9/17)，手術拒否例を 除くと60\%（9/15）であった。他癌死，原因不明死を 除くと69\%（9/13）であった。

4. 17例の治療法とその反省, 最近の治療方針につ いて考察した.

5 年生存率 $50 \%$ の目標は一応達成されたが，5年生 存例が十分満足すべき生活が送れたか自信はない. 形 態と機能の保存, 生存率の向上に更に努力する必要を 痛感した。

\section{参考文献}

1）小野 勇 他：下咽頭頸部食道癌, 遠隔成䋶よりみた治
療方針の検討。癌の臨床 $26: 1169-1173,1980$.

2）高橋廣臣, 岡本牧人, 鈴木 徹, 斉藤 彰, 八尾和雄 他： 上額癌の治療成績 3 年治癁とその治瘜に影響する臨 末的, 病理組織学的因子について。 日耳耳鼻 $84: 868$ $876,1981$.

3）岡本牧人：頭頸部癌患者の血波学的並びに血清学的検 查值の治療による変動に関する臨床的研究。日耳畕 $84: 1408-1423,1981$.

4）高橋廣臣, 岡本牧人, 斉藤 彰, 鈴木 徹：頭頸部癌に 対するクレスチン投与経験。癌と化療 $7: 489-495$, 1980.

5）高橋廣臣, 岡本牧人, 鈴木 徹, 养藤 彰, 八尾和雄他： 頭頸部癌に対する SPG 投与経験。耳鼻と臨床 25 ： 436-442, 1979.

6）宮原 裕：下咽頭癌の実態と治療. 気食 34：123129, 1983.

7）高橋廣臣，岡本牧人，八尾和雄，松林 隆：放射線を中 心とした涘頭癌の治療，耳鼻 23:1-7，1977.

8）熊井和子, 岡本牧人, 高橋廣臣, 八尾和雄：当院におけ 了無峧頭者の音声習得状況. 頭頸部嗹瘍 $12: 386$, 1985.

9）高橋廣臣：高齢者頭頸部癌，特に手術拒否例の治療法 の検討. 昭和57-58年度文部省科学研究費補助金研究 成果報告書 1984 ,

10）齐藤 彰, 鈴木 徹, 八尾和雄, 岡本牧人, 高橋廣臣： 成分栄養法による頭頸部悪性腫瘍術後患者の栄養管理 について。 日耳鼻 85：534-541， 1982.

11) Ariyan $S$ : Further experiences with pectoralis major myocutaneous flap for the immediate repair of defectes from excisions of head and neck cancers. Plast Reconstr Surg 64:605-612, 1979.

12）村上 泰他：大胸筋 Myocutaneous Island Flap k よる頸部食道一期的再建術。気食 $31: 228-237$, 1980.

13）岡本牧人, 高橋廣臣,八尾和雄, 設楽哲也：手術治療を 中心とした口腔悪性腫瘍の治療. JOHNS 2:679684, 1986.

14）猪狩武詔：下咽頭癌の頸部リンパ節転移に関する基礎 的並び臨床的研究。日耳 $89: 629-640 ， 1986$.

15）谷 光毅, 天津睦郎：梨状陌山癌の病理組織学的研究

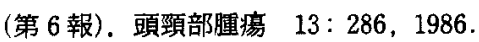

16）佐藤美晴 他：進行した下咽頭頸部食道癌の手術. 手術 37: 771-779, 1983.

17）掛川暉夫：頚部食道癌の外科的治療. 気食 $27: 98-$ 103, 1976.

18）岡田康司 他：下咽頭癌の予後不良因子の推移. 頭頸部 腫嚗 $12: 241,1985$. 
設楽哲也教援の御校閲を深謝する.また, 第 3 次訪米, 頭 莖部外科視察団の斉藤成司前慶応大学教授, 並びに団員の 諸兄に深謝する．特にコーディネータの村上泰慶応大学助 教授にはその後も再建について適切なアドバイスをいただ いた.
本論文の一部は第10回日本頭顓部腫瘍学会において口演 発表した.

（原稿受付 昭和62.12.9日）

別刷請求先 $\overline{\mathbf{T}} 228$ 相模原市北里1-15-1

北里大学医学部耳鼻咽喉科学教室 岡本牧人 